\title{
Cerebral Toxoplasmosis and Associated Risk Factors in People Living with HIV in Kinshasa, Democratic Republic of Congo
}

\author{
Eveline Amaela ${ }^{1,2}$, Aliocha Nkodila ${ }^{3,4}$, Ben Bepouka1, Mireille Longokolo', Mandone Mandina', \\ Nadine Mayasi' ${ }^{1}$, Bijou Magbetha', Florant Kiazayayako', Albert Mbonza ${ }^{1}$, Tranquiline Mabunu ${ }^{1}$, \\ Tharcice Kayembe ${ }^{5}$, Marcel Mbula1, Hippolyte Situakibanza ${ }^{1}$ \\ ${ }^{1}$ Department of Infectious Diseases, University Clinics of Kinshasa, Kinshasa, Democratic Republic of the Congo \\ ${ }^{2}$ Department of Internal Medicine, Central Military Hospital of Kinshasa, Kinshasa, Democratic Republic of the Congo \\ ${ }^{3}$ Faculty of Public Health, Lomo University Research, Kinshasa, Democratic Republic of the Congo \\ ${ }^{4}$ Department of Family Medicine and Primary Care, University Protestant of Congo, Kinshasa, Democratic Republic of the Congo \\ ${ }^{5}$ Department of Neurology, Neuro Psychiatric Center of Kinshasa, Kinshasa, Democratic Republic of the Congo \\ Email: ${ }^{\star}$ nkodilaaliocha@gmail.com
}

How to cite this paper: Amaela, E., Nkodila, A., Bepouka, B., Longokolo, M., Mandina, M., Mayasi, N., Magbetha, B., Kiazayayako, F., Mbonza, A., Mabunu, T., Kayembe, T., Mbula, M. and Situakibanza, H. (2021) Cerebral Toxoplasmosis and Associated Risk Factors in People Living with HIV in Kinshasa, Democratic Republic of Congo. Open Access Library Journal, 8: e8048.

https://doi.org/10.4236/oalib.1108048

Received: October 3, 2021

Accepted: October 24, 2021

Published: October 27, 2021

Copyright $\odot 2021$ by author(s) and Open Access Library Inc.

This work is licensed under the Creative Commons Attribution International License (CC BY 4.0).

http://creativecommons.org/licenses/by/4.0/

\section{Open Access}

\begin{abstract}
Background and Aim: Cerebral toxoplasmosis is a very common opportunistic infection in people living with HIV but the data on this pathology in the DRC are fragmentary. This study aims to assess the extent of cerebral toxoplasmosis and its associated factors in hospitals in the city of Kinshasa. Methods: A cross-sectional study of data was collected from 263 PLHIV in 3 medical hospital facilities in the city of Kinshasa during the period from $01 / 01 / 2008$ to $12 / 31 / 2013$. Data on the socio-demographic, clinical, paraclinical and evolutionary profiles were collected using a questionnaire. A predictive model using logistic regression identified factors associated with cerebral toxoplasmosis at a threshold of $\mathrm{p}<0.05$. Results: The frequency of cerebral toxoplasmosis in PLHIV was $19.4 \%$. The absence of cotrimoxazole prophylaxis (aOR 6.9 95\% CI [2.7 - 17.5]), ART less than 6 months (aOR8.1 95\% CI [3.2 - 21.0], the rate CD4 $<200$ cells $/ \mathrm{mm}^{3}$ (aOR 3.6 95\% CI [1.018 - 12.8]) were independent predictors of cerebral toxoplasmosis. Conclusion: This study found a high prevalence of cerebral toxoplasmosis, similar to other studies. Early management of PLWHA is recommended to reduce this frequency.
\end{abstract}

\section{Subject Areas \\ Infectious Diseases, Public Health}

\section{Keywords}

Cerebral Toxoplasmosis, Associated Factors, Kinshasa Hospitals 


\section{Introduction}

Toxoplasmosis is a disease caused by Toxoplasma gondii ( $T$. gondii), an obligate intracellular parasite that infects virtually all species of warm-blooded animals [1]. The parasite has a worldwide distribution with about a third of the world's population infected. It has a complex life cycle, undergoing the sexual phase in the definitive feline host and the asexual phase in its intermediate hosts [1] [2] [3]. The parasite is transmitted to humans mainly through accidental ingestion of its oocysts from cat faeces, consumption of infected raw meat and rarely vertical transmission during pregnancy [1]. The clinical presentations of the disease are diverse and depend mainly on the immune status of the host. The disease is usually self-limited in immunocompetent individuals, rarely causing pulmonary toxoplasmosis [2]. However, it can cause a fatal disease, cerebral toxoplasmosis (CD), in immunocompromised people [3].

$\mathrm{CD}$ is one of the opportunistic infections causing morbidity and mortality in people living with HIV (PLHIV). Primary infection with the parasite initially gives an IgM immune response, followed by a specific anti-T IgG response gondii. As a result of the host's immune response against $T$. gondii, the cyst stage of the parasite that contains slowly replicating bradyzoites is formed in skeletal muscles and neuronal tissue. However, in immunocompromised individuals, reactivation of $T$. gondii following the conversion of bradyzoites to the proliferative tachyzoite stage may result in toxoplasmic encephalitis (TE) [4]. The risk of $\mathrm{TE}$ increases with a decrease in the number of CD4+ T cells [5].

Several studies have documented the varying extent of cerebral toxoplasmosis in PLHIV. The seroprevalence of CD in people infected with HIV is often high in most studies, with a significant incidence of ET in patients with AIDS who do not receive prophylaxis [6]. Most of the available studies on the extent of $\mathrm{CD}$ in PLHIV have reported a prevalence of over 75\% [7] [8] [9] [10]. In addition, the seroprevalence of $\mathrm{CD}$ of $81.4 \%$ among women of reproductive age in central Africa [11] and 83.6\% among pregnant women in southwest Africa [12] has also been documented. The seroprevalence of TC is similarly high in most countries of sub-Saharan Africa [13] [14] [15].

Laboratory diagnosis of TC in PLHIV is not a common practice in health facilities in the Democratic Republic of Congo (DRC). In addition, data on the seroprevalence of TC are limited in the DRC and published studies on the extent of TC in PLHIV in our environment are absent. Therefore, this study determined the frequency of $\mathrm{CD}$ and assessed the risk factors associated with this opportunistic infection in PLWHIV who frequent hospitals in Kinshasa.

The general objective of this study is to assess the extent of cerebral toxoplasmosis and its associated factors in hospitals in the city of Kinshasa.

\section{Methods}

\subsection{Study Setting and Design}

A cross-sectional study based on the records of people living with HIV was 
conducted at the University Clinics of Kinshasa, at the Provincial General Reference Hospital of Kinshasa and at the Monkole Hospital Center from 01/01/2008 to $12 / 31 / 2013$.

\subsection{Study Population}

Study participants were PLWHIV inhabitants of the city province of Kinshasa. A total of 263 records of HIV-positive people were identified consecutively in the three above-mentioned care centers during the study period. Study participants were diagnosed with HIV and follow-up at all three centers was done. The sample was exhaustive and included PVVs followed in the Internal Medicine Units of three hospitals and who met the inclusion criteria.

To be included in the study, you had to be a PLWHIV diagnosed by 2 rapid tests and/or Elisa and followed in one of these three centers, be at least 14 years old and have a medical file providing the elements of interest, of the study.

\subsection{Data Collection}

Data were obtained using a structured survey form. PLWHIV was admitted consecutively by a documentary review conducted by the principal investigator and her team. This documentary review consisted in reviewing all the files of PLWHIV consulted in these hospitals. A pre-tested questionnaire was used to collect socio-demographic and clinical data on cerebral toxoplasmosis. Data were collected from each file of patients meeting the inclusion criteria. Some of the people living with HIV had had a brain scan, others had not. The variables of interest retained were socio-demographic, clinical, paraclinical (Lab, Imaging), therapeutic and vital outcome: death or cure.

PLHIV: Subject with known HIV (confirmed in the file) by at least two rapid HIV positive tests and/or ELISA positive.

TC+: PVV with suggestive symptomatology (infectious syndrome, signs of intracranial hypertension and signs of localization) and a favorable outcome under antitoxoplasmic treatment based on Cotrimoxazole or Sulfadiazine-Pyrimethamine and/or Roundel image on CT Scan of the brain [11] [12].

- Patient treated with ARVs: any patient who received ARVs beyond 6 months.

- Curative dose with CTX: loading dose with CTX (10 mg/kg/day of Trimethoprim and $50 \mathrm{mg} / \mathrm{kg} /$ day of sulfamethoxazole) $3 \mathrm{X} /$ day by infusion or per os for 6 to 8 weeks.

\subsection{Statistical Analysis}

Analyses were performed using SPSS 22.0. Descriptive statistics consisted of calculating the mean and standard deviation for quantitative data and the proportions for categorical data. Pearson's chi-squared test or Fisher's exact test was used to comparing the proportions, while the Student's $t$-test was used to compare the means. The research for the factors associated with cerebral toxoplasmosis was carried out by the logistic regression test in univariate analysis. When 
differences were observed between cerebral toxoplasmosis and the independent variables, the effect of potential confounders was investigated by logistic regression adjustment in multivariate analysis. Finally, the odds ratios (ORs) and their 95\% confidence intervals (95\% CIs) were calculated to determine the degree of association between cerebral toxoplasmosis and the independent variables. A p value $<0.05$ was considered to be the threshold of statistical significance.

\subsection{Ethical Considerations}

The data were collected anonymously and confidentially. The privacy and confidentiality of the respondents were safeguarded. The three fundamental principles of ethics were respected at the time of the study, namely: the principle of respect for the person, that of beneficence, and that of justice.

\section{Results}

\subsection{Frequency of Cerebral Toxoplasmosis}

Out of 263 records of PLWHA collected in the 3 hospitals, 51 cases of cerebral toxoplasmosis were identified, i.e. a frequency of $19.4 \%$.

\subsection{Sociodemographic Characteristics of the PLWHIV under Study}

The mean age of the patients was $42.6 \pm 11.7$ years with extremes of 16 years and 71 years, $31.4 \%$ of these patients were between 30 and 39 years old. A male predominance was noted with $53.8 \%$ of men and $46.2 \%$ of women with a sex ratio of 1.3 . The majority of these patients were unemployed (49.8\%); $49.1 \%$ of the patients were married and 39\% attended revival churches (Table 1).

\subsection{Clinical, Paraclinical and Therapeutic Characteristics}

Statistically significant and suggestive signs of cerebral toxoplasmosis were excruciating headache, coma, signs of lateralization, convulsions, and meningeal signs. With regard to vital signs, it appears that the mean PAM was significantly higher in PLWHIV with TC ( $\mathrm{p}=0.008)$; On the other hand, the CD4 count was more collapsed in patients with $\mathrm{CD}$ when comparing the medians of two groups. Patients with CT had a low frequency of primary CTX prophylaxis and their rate of ARV intake was low. Note that 16 PLHIV carried a cerebral CT Scan protocol; the tomodensitometric appearances were hypodense (65.5\%), cockade (65.5\%), nodular (37.5\%) and rounded (31.3\%) images (Table 2).

\subsection{Risk Factors Associated with Cerebral Toxoplasmosis}

On univariate analysis, lack of cotrimoxazole prophylaxis, taking ARVs for less than 6 months, and $\mathrm{CD} 4$ count $<200$ cells $/ \mathrm{mm}^{3}$ emerged as risk factors associated with $\mathrm{CD}$.

After adjustment, in multivariate analysis, all univariate factors had emerged as risk factors associated with cerebral toxoplasmosis. The absence of cotrimoxazole prophylaxis (adjusted OR 6.9 95\% CI [2.7 - 17.5]), ART less than 6 months 
Table 1. Sociodemographic characteristics and status of toxoplasmosis.

\begin{tabular}{|c|c|c|c|c|}
\hline Variables & $\begin{array}{c}\text { Over all } \\
n=263(\%)\end{array}$ & $\begin{aligned} & \mathrm{TE}- \\
& \mathrm{n}= 212(\%)\end{aligned}$ & $\begin{array}{c}\mathrm{TE}+ \\
\mathrm{n}=51(\%)\end{array}$ & $\mathrm{p}$ \\
\hline Gender & & & & 0.373 \\
\hline Male & $140(53.8)$ & $111(53.1)$ & $29(56.9)$ & \\
\hline Female & $120(46.2)$ & $98(46.9)$ & $22(43.1)$ & \\
\hline Age (years) & & & & 0.899 \\
\hline$<30$ & $31(12.2)$ & $24(11.8)$ & $7(13.7)$ & \\
\hline $30-39$ & $80(31.4)$ & $62(30.4)$ & $18(35.3)$ & \\
\hline $40-49$ & $74(29.0)$ & $61(29.9)$ & $13(25.5)$ & \\
\hline$\geq 50$ & $70(27.4)$ & $57(27.9)$ & $13(25.4)$ & \\
\hline Marrital status & & & & 0.078 \\
\hline Married & $125(49.1)$ & $99(48.3)$ & $26(52.0)$ & \\
\hline Single & $75(29.4)$ & $58(28.3)$ & $17(34.0)$ & \\
\hline Widower & $37(14.5)$ & $35(17.1)$ & $2(4.0)$ & \\
\hline Divorced & $18(7.1)$ & $13(6.3)$ & $5(10.0)$ & \\
\hline Profession & & & & 0.088 \\
\hline Unemployed & $119(49.8)$ & $96(50.0)$ & $23(48.9)$ & \\
\hline Independent & $41(17.2)$ & $34(17.7)$ & $7(14.9)$ & \\
\hline State worker & $65(27.1)$ & $51(26.6)$ & $14(29.8)$ & \\
\hline Student & $14(5.9)$ & $11(5.7)$ & $3(6.4)$ & \\
\hline Religion & & & & 0.343 \\
\hline Revival Church & $39(39.0)$ & $34(42.0)$ & $5(26.3)$ & \\
\hline Catholic & $36(34.0)$ & $28(32.1)$ & $8(42.1)$ & \\
\hline Protestant & $18(18.0)$ & $14(17.3)$ & $4(21.1)$ & \\
\hline Other & $7(7.0)$ & $5(6.2)$ & $2(10.6)$ & \\
\hline
\end{tabular}

Table 2. Clinical, paraclinical and therapeutic characteristics according to TE.

\begin{tabular}{lcccc}
\hline \multicolumn{1}{c}{ Variable } & $\begin{array}{c}\text { Over all } \\
\mathbf{n}=\mathbf{2 6 3 ( \% )}\end{array}$ & $\begin{array}{c}\text { TE- } \\
\mathbf{n}=\mathbf{2 1 2}(\%)\end{array}$ & $\begin{array}{c}\text { TE+ } \\
\mathbf{n}=\mathbf{5 1}(\%)\end{array}$ & $\mathbf{p}$ \\
\hline Excruciating headaches & $73(28.1)$ & $46(22.0)$ & $27(52.9)$ & $<0.001$ \\
Coma & $44(16.7)$ & $17(8.2)$ & $27(52.9)$ & $<0.001$ \\
Lateralization sign & $43(16.3)$ & $10(4.7)$ & $33(64.7)$ & $<0.001$ \\
Convulsions & $16(6.2)$ & $4(1.9)$ & $12(23.5)$ & $<0.001$ \\
Meningeal signs n (\%) & $53(20.7)$ & $26(12.6)$ & $27(54.0)$ & $<0.001$ \\
MBP & $80.7 \pm 16.3$ & $79.4 \pm 15.6$ & $86.1 \pm 18.0$ & $\mathbf{0 . 0 0 8}$ \\
HR. bpm & $98.5 \pm 19.1$ & $99.4 \pm 19.1$ & $94.8 \pm 18.7$ & 0.132 \\
FR. cpm & $27.7 \pm 8.7$ & $28.3 \pm 9.2$ & $25.3 \pm 5.4$ & 0.339 \\
CD4 (cell/mm $\left.{ }^{3}\right)$ & $110(94.0-127.0)$ & $114(96.5-150)$ & $98(74.0-126.0)$ & $\mathbf{0 . 0 1 4}$ \\
Cx Prophylaxis & $169(66.8)$ & $150(73.5)$ & $19(38.8)$ & $<0.0001$ \\
ARV Treatment & & & & $<0.0001$ \\
\multicolumn{1}{c}{ No } & $70(33.3)$ & $40(23.8)$ & $30(71.4)$ & \\
\multicolumn{1}{c}{ Yes } & $140(66.7)$ & $128(76.2)$ & $12(28.6)$ & \\
\hline
\end{tabular}


(adjusted OR $8.195 \%$ CI [3.2 - 21.0], the CD4 count $<200$ cells $/ \mathrm{mm}^{3}$ (adjusted OR $3.695 \%$ CI [1.018 - 12.8]) increased the risk of developing CD by 7,8 and 4 , respectively (Table 3 ).

\section{Discussion}

In this study, the seroprevalence of cerebral toxoplasmosis was $19.4 \%$ in HIV-positive patients. Cerebral toxoplasmosis is a major opportunistic parasitic infection in people infected with HIV [16], especially when the CD4+ T lymphocyte count falls below 100 cells/ $\mu \mathrm{L}$ [17]. The high prevalence of toxoplasmosis in PLWHA in this study, therefore, highlights the need for prevention of all PLHIV by CT scan imaging [18]. This requires regular monitoring of people infected with HIV and treatment of eligible subjects [19]. Cerebral toxoplasmosis is also likely to be very common in people with unrecognized HIV infection, putting them at high risk of death. Cerebral toxoplasmosis is one of the central nervous system disorders and opportunistic infections that define AIDS in patients with HIV/AIDS [20] [21] [22]. Screening for cerebral toxoplasmosis in people infected with HIV is not a common practice in care centers in Kinshasa. The high prevalence of cerebral toxoplasmosis in PLWHIV in this study warns healthcare professionals to consider this infection opportunistic to prevent the neurological complications associated with it. The prevalence of cerebral toxoplasmosis in this study among PLHIV appears to be lower than the studies by Bahir Dar [23] and Addis Ababa [24], where the prevalence of $87.4 \%$ and $93.3 \%$ was documented, respectively. In contrast, a relatively similar prevalence has been found in several African studies [25] [26].

Headaches, coma and convulsions were the main reasons for consultation found in our patients, as noted in the African series [27]. The average consultation time for our patients seemed long. These long delays are common to several authors [28]. The denial of the HIV disease specific to the populations studied, the low socio-economic level and the use of traditional treatments partly justify this delay in consultation found in sub-Saharan Africa. Meningeal signs and focal

Table 3. Risk factors associated with CD in PLHIV logistic regression analysis.

\begin{tabular}{|c|c|c|c|c|}
\hline Independants factors & $\mathrm{p}$ & Unadjusted OR (IC 95\%) & $\mathrm{p}$ & Adjusted OR (IC 95\%) \\
\hline \multicolumn{5}{|l|}{ Cx Prophylaxis } \\
\hline Yes & & 1 & & 1 \\
\hline No & $<0.001$ & $4.4(2.3-8.4)$ & $<0.001$ & $6.9(2.7-17.5)$ \\
\hline \multicolumn{5}{|l|}{ Duration of ARV intake } \\
\hline$\geq 6$ months & & 1 & & 1 \\
\hline$<6$ months & $<0.001$ & $8.0(3.8-17.1)$ & $<0.001$ & $8.1(3.2-21.0)$ \\
\hline \multicolumn{5}{|l|}{ CD4 } \\
\hline$\geq 200$ élts $/ \mathrm{mm}^{3}$ & & 1 & & 1 \\
\hline$<200$ élts $/ \mathrm{mm}^{3}$ & 0.024 & $3.5(1.2-10.6)$ & 0.047 & $3.6(1.02-12.8)$ \\
\hline
\end{tabular}


signs were the most common on examination of the neurological system, indicating the advanced stage of the patients' immune status. Indeed, the attack of the central nervous system during the TC in the PLWHIV is frequent and is the consequence either of the immunosuppression induced by the virus of the HIV, or of the attack of the CNS by the toxoplasm Gondi itself, or side effects linked to antiretroviral treatments including immune restoration and/or direct toxicity [29]. Cotrimoxazole prophylaxis and ART offer a significant improvement in the quality of life of people living with HIV, preventing weakening of their immune system and reducing the onset of opportunistic infections [30]. Cotrimoxazole prophylaxis and ARV therapy were not used regularly, only $66.8 \%$ and $66.7 \%$, respectively, of the patients in this study, had received these treatments. This is in agreement with the data reported in the study carried out in Recife [31]. The mean CD4 of TC+ patients was significantly lower compared to patients without TC, which means a high risk of disease reactivation, progression to AIDS and establishment of opportunistic infections are high [32]. It is clear that some difficulties must be overcome, such as non-compliance with treatment and the correct use of drugs aimed at improving the quality of life and the length of life of these patients [33].

After adjustment in multivariate analysis, the absence of cotrimoxazole prophylaxis (adjusted OR 6.9 95\% CI [2.7 - 17.5]), ART less than 6 months (adjusted OR 8.1 95\% CI [3.2 - 21.0], CD4 count $<200$ cells $/ \mathrm{mm}^{3}$ (adjusted OR 3.6 95\% CI [1.018 - 12.8]) were the independent factors associated with cerebral toxoplasmosis and respectively multiplied by 7,8 and 4 the risk of developing $\mathrm{CD}$ All of these determinants are linked to cerebral toxoplasmosis through the weakening of their immune system and thus increasing the risk of developing opportunistic infections.

\section{Conclusion}

The frequency of cerebral toxoplasmosis is very high in the population of PLHIV in Kinshasa. This frequency is associated with the absence of cotrimoxazole prophylaxis, the length of time you take ARVs and the low CD count. Good monitoring of PLWHA could reduce this rate of cerebral toxoplasmosis.

\section{Acknowledgements}

The authors would like to thank the staff members of the 3 study formations (CUK, CH Monkole and HPGRK) for their cooperation during data collection. They are also grateful to the Laboratory staff and to the PLWHIV followed in these 3 training courses.

\section{Authors' Contributions}

Amaela E designed the study; Nkodila A participated in statistical data analysis; Bepouka B, Longokolo M, Mandina M, Mayasi N, Magbetha B, Kiazayayako F, Mbonza A and Mabunu T participated in data design and acquisition; Kayembe 
T, Situakibanza $\mathrm{H}$ and Mbula M supervised the study. All authors contributed to the drafting of the document and approved the final document.

\section{Conflicts of Interest}

The authors declare no conflicts of interest.

\section{References}

[1] Dubey, J.P. (2010) Toxoplasmose d'animaux et d'humains. CRC Press, Beltsville.

[2] Leal, F.E., Cavazzana, C.L., de Andrade, H.F., Galisteo, A.J., de Mendonça, J.S. and Kallas, E.G. (2007) Toxoplasma gondii Pneumonia in Immunocompetent Subjects: Case Report and Review. Clinical Infectious Diseases, 44, e62-e66. https://doi.org/10.1086/511871

[3] Kodym, P., Malý, M., Béran, G., Jilich, D., Rozsypal, H., Machala, L. and Holub, M. (2014) Incidence, Immunological and Clinical Characteristics of Reactivation of Latent Toxoplasma gondii Infection in HIV-Infected Patients. Epidemiology and Infection, 143, 600-607.

[4] Luma, H.N., Tchaleu, B.C.N., Mapoure, Y.N., Temfack, E., Doualla, M.S., Halle, M.P., et al. (2013) Toxoplasma Encephalitis in HIV/AIDS Patients Admitted to the Douala General Hospital between 2004 and 2009: A Cross Sectional Study. BMC Research Notes, 6, Article No. 146. https://doi.org/10.1186/1756-0500-6-146

[5] Djurković-Djaković, O., Bobić, B., Vuković, D., Juge, M. and Jevtović, D. (1997) Risk of Toxoplasmic Encephalitis in AIDS Patients in Yugoslavia. International Journal of Infectious Diseases, 2, 74-78. https://doi.org/10.1016/S1201-9712(97)90085-0

[6] Nascimento, L.V., Stollar, F., Tavares, L.B., Cavasini, C.E., Maia, I.L. and Cordeiro, J.A. (2001) Risk Factors for Toxoplasmic Encephalitis in HIV-Infected Patients: A Case-Control Study in Brazil. Annals of Tropical Medicine and Parasitology, 95, 587-593. https://doi.org/10.1080/00034980120073931

[7] Woyneshet, G., Tadesse, K. and Asrat H. (2015) High Prevalence of Anti-Toxoplasma Antibodies and Absence of Toxoplasma gondii Infection Risk Factors among Pregnant Women Attending Routine Antenatal Care in Two hospitals of Addis Ababa, Ethiopia. International Journal of Infectous Desease, 34, 41-45. https://doi.org/10.1016/j.ijid.2015.03.005

[8] Foroutan, M., Dalvand, S., Daryani, A., Ahmadpour, E., Majidiani, H., Khademvatan, S., et al. (2018) Rolling up the Pieces of a Puzzle: A Systematic Review and Meta-Analysis of the Prevalence of Toxoplasmosis in Iran. Alexandria Journal of Medicine, 54, 189-196. https://doi.org/10.1016/j.ajme.2017.06.003

[9] Muluye, D., Wondimeneh, Y. and Belyhun, Y. (2013) Prevalence of Toxoplasma gondii and Associated Risk Factors among People Living with HIV at Gondar University Hospital, Northwest Ethiopia. International Scholarly Research Notices, 2013, Article ID: 123858. https://doi.org/10.1155/2013/123858

[10] Haileluel, A., Getachew, T., Daniel, F., Nega, B. and Girmay, M. (2013) Seroprevalence of Immunoglobulin-G and Anti-Toxoplasma gondii Antibodies of Immunoglobulin-M in Patients Infected with Human Immunodeficiency Virus/Acquired Immunodeficiency at Tikur Anbessa Specialized Hospital Addis Ababa, Ethiopia. Journal of Infectious Diseases and Therapy, 1, 119.

[11] Gebremedhin, E.Z., Abebe, A.H., Tessema, T.S., Tullu, K.D., Medhin, G., Vitale, M., Di Marco, V., Cox, E. and Dorny, P. (2013) Seroepidemiology of Toxoplasma gon- 
dii Infection in Women of Childbearing Age in Central Ethiopia. BMC Infectious Diseases, 13, Article No. 101. https://doi.org/10.1186/1471-2334-13-101

[12] Zemene, E., Yewhalaw, D., Abera, S., Belay, T., Samuel, A. and Zeynudin, A. (2012) Toxoplasma gondii Seroprevalence and Associated Risk Factors in Pregnant Women in the Town of Jimma, Southwest Ethiopia. BMC Infectious Disease, 12, Article No. 337. https://doi.org/10.1186/1471-2334-12-337

[13] Ayi, I., Edu, S.A. and Apea-Kubi, K.A. (2009) Séroépidémiologie de la toxoplasmose chez les femmes enceintes dans la grande région d'Accra au Ghana. Ghana Medical Journal, 43, 107-114. https://doi.org/10.4314/gmj.v43i3.55325

[14] Addebbous, A., Adarmouch, L., Tali, A., Laboudi, M., Amine, M., Aajly, L., Rhajaoui, M., Chabaa, L. and Zougaghi, L. (2012) Anticorps anti-toxoplasma IgG chez des patients asymptomatiques infectés par le VIH à Marrakech-Maroc. Acta Tropica, 123, 49-52. https://doi.org/10.1016/j.actatropica.2012.02.070

[15] Bigna, J.J., Tochie, J.N., Tounouga, D.N., Bekolo, A.O., Ymele, N.S. and Youda, E.L. (2020) Global, Regional, and Country Seroprevalence of Toxoplasma gondii in Pregnant Women: A Systematic Review, Modelling and Meta-Analysis. Scientific Reports, 10, Article No. 12102. https://doi.org/10.1038/s41598-020-69078-9

[16] Lindström, I., Kaddu-Mulindwa, D.H., Kironde, F. and Lindh, J. (2006) Prévalence de parasites Toxoplasmagondii latents et réactivés chez des patients infectés par le VIH en Ouganda. Acta Tropica, 100, 218-222. https://doi.org/10.1016/j.actatropica.2006.11.002

[17] Malik, A.K. and Al Hilli, F. (2009) Toxoplasmose cérébrale chez un patient séropositif: Rapport de cas et revue de pathogenèse et de diagnostic en laboratoire. Bulletin Médical de Bahreïn, 31, 1-5.

[18] Centres pour le contrôle et la prévention des maladies (2009) Directives pour la prévention et le traitement des infections opportunistes chez les adultes et les adolescents infectés par le VIH. Centres pour le contrôle et la prévention des maladies, Atlanta.

[19] Kodym, P., Malı, M., Beran, O., Jilich, D., Rozsypal, H. and Machala, L. (2014) Incidence, caractéristiques immunologiques et cliniques de la réactivation de l'infection latente de Toxoplasma gondii chez des patients infectés par le VIH. Epidémiologie et Infection, 22, 1-8.

[20] Dai, L., Mahajan, S.D., Guo, C., Zhang, T., Wang, W., Li, T., Jiang, T., Wu, H. and Li, N. (2014) Spectre des troubles du système nerveux central chez les patients hospitalisés VIH/SIDA (2009-2011) à un important centre de référence sur le VIH/SIDA à Beijing, en Chine. Journal des Sciences Neurologiques, 342, 88-92. https://doi.org/10.1016/j.jns.2014.04.031

[21] Balkhair, A.A., Al-Muharrmi, Z.K., Ganguly, S. and Al-Jabri, A.A. (2012) Spectre du SIDA définissant les infections opportunistes dans une série de 77 patients Omanis infectés par le VIH hospitalisés. Sultan Qaboos University Medical Journal, 12, 442-448. https://doi.org/10.12816/0003169

[22] Berhe, T., Melkamu, Y. and Amare, A. (2012) Le modèle et les prédicteurs de la mortalité des patients atteints du VIH/SIDA avec manifestation neurologique en Ethiopie: Une étude rétrospective. Sida et la Thérapie, 9, Article No. 11.

[23] Walle, F., Kebede, N., Tsegaye, A. and Kassa, T. (2013) Seroprevalence and Risk Factors for Toxoplasmosis in HIV-Infected and Uninfected People in Bahir Dar, Northwest Ethiopia. Parasites and Vectors, 6, Article No. 15.

[24] Shimelis, T., Tebeje, M., Tadesse, E., Tegbaru, B. and Terefe, A. (2009) Sero-Prevalence of Latent Infection with Toxoplasma gondii in HIV-Infected and 
Non-HIV-Infected People in Addis Ababa, Ethiopia: Comparative Study between Cross-Sectional Studies. BMC Research Notes, 2, Article No. 213. https://doi.org/10.1186/1756-0500-2-213

[25] Nissapatorn, V., Lee, C., Quek, K.F., Leong, C.L., Mahmoud, R. and Abdullah, K.A. (2004) Toxoplasmose chez les patients atteints du VIH/SIDA: Une situation actuelle. Journal japonais des maladies infectieuses, 57, 160-165.

[26] Alvarado-Esquivel, C., Pacheco-Vega, S.J. and Hernández-Tinoco, J. (2014) Séroprévalence de l'infection à Toxoplasma gondii et facteurs de risque associés chez les Huicholes au Mexique. Parasites et Vecteurs, 7, Article No. 301. https://doi.org/10.1186/1756-3305-7-301

[27] Ouatarra, B., Eholié, S.P. and Adoubryn, K.D. (2007) Commentaires sur Etude rétrospective des méningites bactériennes et à cryptocoques chez des sujets adultes infectés par le VIH à Abidjan. Journal de Mycologie Médicale, 17, 87-88.

https://doi.org/10.1016/j.mycmed.2007.02.004

[28] Millogo, A., Ki-Zerbo, G.A. and Andonaba, J.B. (2004) La Cryptococcose neuroméningée au cours de l'infection par le VIH au Centre hospitalier de Bobo-Dioulasso (Burkina Faso). Bulletin de la Société de Pathologie Exotique, 97, 119-121.

[29] Manga, N.M., Diop, S.A., Ndoura, C.T., Dia, N.M., Mendy, A., Coudec, M., et al. (2009) Late Diagnosis of HIV Infection at the Infectious Diseases Clinic of Fann, Dakar: Circumstances of Screening, Treatment Course of Patients and Determining Factors. Médecine et Maladies Infectieuses, 39, 95-100. https://doi.org/10.1016/j.medmal.2008.09.021

[30] Moulignier, A. (2006) Atteintes du système nerveux central et infection par le VIH-1. Revue Neurologique (Paris), 162, 22-42. https://doi.org/10.1016/S0035-3787(06)74980-3

[31] Ministère de la Santé (2008) Brésil. Secretaria de Vigilância em Saúde. Programme national de DST et SIDA. Recommandações para terapia antirretroviral en adultos infectados pelo HIV. SVS/PNDST SIDA, Brasília.

[32] Wallace, G.R. and Stanfort, M.R. (2008) Immunité et Toxoplasma rétinochoroiditis. Clinical \& Experimental Immunology, 153, 309-315.

[33] Spalding, S.M., Amendoeira, M.R.R., Ribeiro, L.C., Silveira, C., Garcia, A.P. and Camillo-Coura, L. (2003) Estudo prospective de gestantes et de ses bebés avec le risque de transmission de toxoplasmose congénita en município do Rio Grande do Sul. Revista da Sociedade Brasileira de Medicina Tropical, 36, 483-491. https://doi.org/10.1590/S0037-86822003000400009 